\title{
3D CFD Electrochemical and Heat Transfer Model of an Internally Manifolded Solid Oxide Electrolysis Cell
}

\section{IMECE 2011}

\author{
Grant L. Hawkes \\ James E. O'Brien \\ Greg G. Tao
}

\section{November 2011}

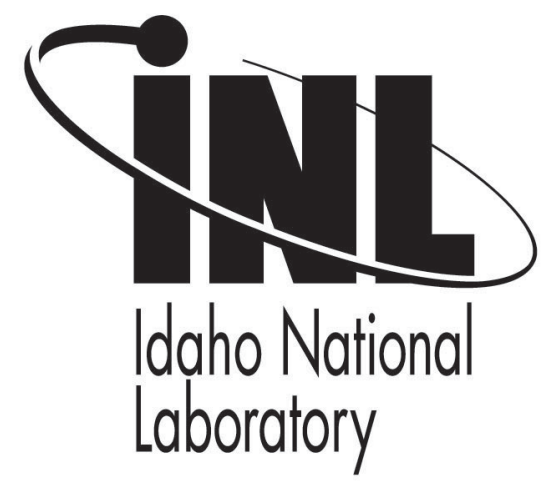

This is a preprint of a paper intended for publication in a journal or proceedings. Since changes may be made before publication, this preprint should not be cited or reproduced without permission of the author. This document was prepared as an account of work sponsored by an agency of the United States Government. Neither the United States Government nor any agency thereof, or any of their employees, makes any warranty, expressed or implied, or assumes any legal liability or responsibility for any third party's use, or the results of such use, of any information, apparatus, product or process disclosed in this report, or represents that its use by such third party would not infringe privately owned rights. The views expressed in this paper are not necessarily those of the United States Government or the sponsoring agency. 


\section{D CFD ELECTROCHEMICAL AND HEAT TRANSFER MODEL OF AN INTERNALLY MANIFOLDED SOLID OXIDE ELECTROLYSIS CELL}

\author{
Grant L. Hawkes \\ Idaho National Laboratory \\ Idaho Falls, Idaho, USA
}

\author{
James E. O'Brien \\ Idaho National Laboratory \\ Idaho Falls, Idaho, USA
}

\author{
Greg G. Tao \\ MSRI \\ Salt Lake City, Utah, USA
}

\begin{abstract}
A three-dimensional computational fluid dynamics (CFD) and electrochemical model has been created to model hightemperature electrolysis cell performance and steam electrolysis in an internally manifolded planar solid oxide electrolysis cell (SOEC) stack. This design is being evaluated experimentally at the Idaho National Laboratory (INL) for hydrogen production from nuclear power and process heat. Mass, momentum, energy, and species conservation are numerically solved by means of the commercial CFD code FLUENT. A solid-oxide fuel cell (SOFC) model adds the electrochemical reactions and loss mechanisms and computation of the electric field throughout the cell. The FLUENT SOFC user-defined subroutine was modified for this work to allow for operation in the SOEC mode. Model results provide detailed profiles of temperature, operating potential, steam-electrode gas composition, oxygen-electrode gas composition, current density and hydrogen production over a range of stack operating conditions. Results will be presented for a five-cell stack configuration that simulates the geometry of five-cell stack tests performed at the INL and at Materials and System Research, Inc. (MSRI). Results will also be presented for a single cell that simulates conditions in the middle of a large stack. Flow enters the stack from the bottom, distributes through the inlet plenum, flows across the cells, gathers in the outlet plenum and flows downward making an upside-down "U" shaped flow pattern. Flow and concentration variations exist downstream of the inlet holes. Predicted mean outlet hydrogen and steam concentrations vary linearly with current density, as expected. Contour plots of local electrolyte temperature, current density, and Nernst potential indicate the effects of heat transfer, reaction cooling/heating, and change in local gas composition.
\end{abstract}

Results are discussed for using this design in the electrolysis mode. Discussion of thermal neutral voltage, enthalpy of reaction, hydrogen production, cell thermal efficiency, cell electrical efficiency, and Gibbs free energy are discussed and reported herein.

\section{INTRODUCTION}

A research program is under way at the Idaho National Laboratory (INL) to simultaneously address the research and scale-up issues associated with the implementation of hightemperature electrolysis for large-scale hydrogen production from nuclear energy [1,2]. The research program includes both experimental work and CFD modeling aimed at performance characterization of electrolysis cells and stacks. Various stack configurations of electrolysis cells [3] have been analyzed showing the importance of flow distribution through large planar stacks. Previous models [4] also included consideration of externally manifolded planar cross flow designs. The INL research program also includes materials development tasks. In the present work, two three-dimensional computational fluid dynamics (CFD) models have been created to analyze hightemperature steam electrolysis in a planar cross-flow internally manifolded solid oxide electrolysis stack. The first model represents a stack of five cells that simulates the geometry of five-cell stack tests performed at INL and at MSRI. The second model is for a single cell stack. Details of the model geometry are specific to cells, fabricated by MSRI [5]. The MSRI cell is compared to experimental tests performed at the INL.

\section{NOMENCLATURE}

$\begin{array}{ll}A S R & \text { Area specific resistance } \\ E & \text { voltage potential, V } \\ F & \text { Faraday constant, } 96487 \mathrm{~J} / \mathrm{V} \text {-gmol } \\ \Delta G & \text { Gibbs free energy, J/gmol } \\ \Delta H & \text { molar enthalpy of reaction, J/gmol } \\ i & \text { current density, } \mathrm{A} / \mathrm{m}^{2} \\ I & \text { current, A }\end{array}$




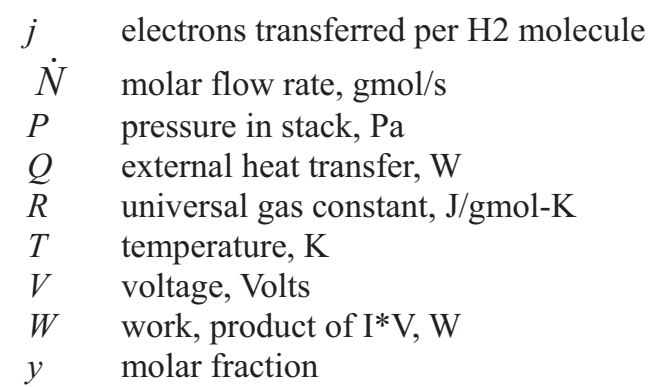

$\begin{array}{ll}\text { Greek Letters } \\ \gamma & \text { molar exponent } \\ \eta & \text { efficiency } \\ \text { Subscripts } \\ \text { act } & \text { activation overpotential } \\ \text { eff } & \text { effective } \\ H 2 & \text { Hydrogen gas } \\ H 2 O & \text { steam } \\ \text { max } & \text { maximum } \\ o & \text { open-cell } \\ \text { O2 } & \text { Oxygen } \\ R & \text { reaction } \\ r e f & \text { reference } \\ \text { std } & \text { standard pressure } \\ t n & \text { thermal neutral }\end{array}$

\section{NUMERICAL MODEL AND DISCUSSION}

The numerical models developed for this paper are based on the geometry of a five-cell and single cell SOEC stack designed and fabricated by MSRI and tested at the INL. An illustration of the experiment test fixture is shown in Figure 1. Cells have a square profile with outer dimensions of $15.2 \mathrm{~cm} \mathrm{x}$ $15.2 \mathrm{~cm}$ and a per-cell active area of $100 \mathrm{~cm}^{2}$. The internally manifolded stack is designed to operate in an upside-down " $U$ " shaped flow pattern, with the steam/hydrogen gas mixture entering the inlet manifold on the bottom in the illustration in Figure 1. The cell operates in cross flow where the steam/hydrogen flow direction is perpendicular to the air/oxygen flow.

The numerical domain extends from the bottom thick metal current collector plate on the bottom that is grounded, to the top of the upper metal current collector plate where the current is distributed. Table 1 depicts the layers that comprise a single cell. The typical cell repeat unit starts from the one-half thickness separator plate with various layers continuing up until the top as a one-half separator plate.
Table 1. Layers comprising repeat unit cell.

SS Separator Plate (1/2 Thickness)
O2 Flow Channel (grill)
O2 Mesh
O2 Electrode
O2 Functional Layer
Electrolyte (no thickness)
H2 Functional Layer
H2 Electrode
H2 Mesh
H2 Flow Channel (grill)
Separator Plate (1/2 Thickness)

The wire meshes shown in Table 1 serve as a method of ensuring good electrical contact between the grill and electrode and also allowing flow to distribute evenly.

The FLUENT SOFC module treats the electrolyte as a 2-D planar element. Therefore the electrolyte in the model has geometrical thickness of zero. On either side of the electrolyte are the electrodes that are created with 3-D elements. Therefore, the electrolyte/electrode assembly in the model is only as thick as the two electrodes. For this electrodesupported cell design, the missing electrolyte thickness is not significant, compared to the electrode thicknesses. The grills are modeled as an anisotropic porous media. The grills shown in Table 1 are described as a sheet of metal with several long slender slots cut through it that allow electrical current to be passed through and flow to be passed along the channels formed by the slots. The permeability of the square channels is calculated as $\mathrm{D}_{\mathrm{H}}^{2} / 32$, where $\mathrm{D}_{\mathrm{H}}$ is the hydraulic diameter. This calculation is independent of length and is found by setting the pressure drop of laminar flow through a rectangular tube equal to that of a fluid in a Darcy porous media where $\mathrm{dP} / \mathrm{dx}=\mu \mathrm{u} / \mathrm{k}$, where $\mu$ is viscosity, $\mathrm{u}$ is velocity, and $\mathrm{k}$ is permeability. Reynolds numbers are very low, around 10.

The numerical grid used in this study includes a $60 \times 60$ mesh in the active cell area in the $\mathrm{X}$ and $\mathrm{Y}$ directions. Flow enters in the round tubes below the inlets and exit in the round tubes at the same height as the inlets. Each flow channel (current collector) has 10 numerical cells through its thickness, whereas each electrode has three elements through its thickness. Figure 2 shows a top view of the grid that is uniform in the $\mathrm{Z}$ direction. Grid refinement results obtained in reference [6] indicated good agreement with as rough as a $5 \times 5$ grid, whereas the grid for this model is $60 \times 60$ for the electrolyte area. The five cell mesh has 3.45 million numerical cells and 3.75 million nodes. Figure 3 shows the mesh for the five cell stack from a perspective view. The mesh shown in Figure 2 is protruded through the entire 3-D model. 
Flow enters the domain in the steam/hydrogen inlet tube and the air inlet tube at $1073 \mathrm{~K}$. Each flow stream then enters a long slot plenum and is distributed through the four slot holes and then horizontally through the grills. Black body radiation to the oven is assumed for all external surfaces with an emissivity of the stainless steel specified at 0.4 . This value is probably low since the surfaces all become oxidized and black in appearance. The mole fraction of hydrogen at the inlet is set at 0.50 , while the steam mole fraction is set at 0.50 . This set of conditions is termed "INL test", whereas the MSRI suggested test conditions have the steam entering at 0.70 and hydrogen at 0.30 for mole fractions.

A voltage boundary condition of 0.0 was set on the bottom of the model and a current of -20.0 Amps was set on the top of the model. Details of the electrochemical model used in the FLUENT SOFC are found in various publications from the author and in the manual itself.

Standard permeability values were specified for the electrodes along with typical values [7] for porosity and tortuosity.

In the electrolysis mode, the net heat flux to the stack is negative at low current densities, increasing to zero at the current density corresponding to the "thermal-neutral" voltage (1.287 V/cell), and positive at higher current densities. Assuming the process occurs at a specified temperature, the thermal-neutral voltage can be predicted from direct application of the First Law to the overall system:

$$
Q-W=\dot{N}_{H 2} \Delta H_{R}
$$

Letting $Q=0$ (no external heat transfer), $W=V I$, and noting that the electrical current is directly related to the molar production rate of hydrogen by

$$
\dot{N}_{H 2}=I / 2 F
$$

where $F$ is the Faraday number $(\mathrm{F}=96,487 \mathrm{~J} / \mathrm{V}$-gmol $)$, yields:

$$
V_{t n}=-\Delta H_{R} / 2 F
$$

Since the molar enthalpy of reaction, $\Delta H_{R}$, is strictly a function of temperature (albeit a very weak function), the thermal-neutral voltage is also strictly a function of temperature, independent of cell ASR and gas compositions. The particular values of net cell heat flux at other operating voltages do however depend on cell ASR and gas compositions. The thermal-neutral voltage increases only slightly in magnitude over the typical operating temperature range for steam electrolysis cells, from $1.287 \mathrm{~V}$ at $800^{\circ} \mathrm{C}$ to $1.292 \mathrm{~V}$ at $1000^{\circ} \mathrm{C}$. Stack operation at or below the thermal-neutral voltage simplifies thermal management of the stack since excess air flow is not required. In fact, in the electrolysis mode, since oxygen is being produced, there is also no theoretical need for air flow to support the reaction at all. In a large-scale electrolysis plant, the pure oxygen produced by the process could be saved as a valuable commodity. Careful consideration must be given, however, to the choice of materials for containing pure oxygen at elevated temperatures. In addition, it may be desirable to sweep with air or some other gas in order to minimize the effects of any hydrogen leakage.
A thermal efficiency, $\eta_{t}$, can be defined for electrolysis cells, analogous to the fuel cell efficiency definition presented in textbooks on fuel cells. The thermal efficiency quantifies the heating value of the hydrogen produced by electrolysis per unit of electrical energy consumed in the stack. Based on this definition,

$$
\eta_{t}=\frac{\Delta H_{R} \dot{N}_{H 2}}{V I}
$$

Eliminating the current I, the thermal efficiency can be expressed in terms of cell operating potential as:

$$
\eta_{t}=\frac{\Delta H_{R} / 2 F}{V}=\frac{V_{t n}}{V} .
$$

The thermal efficiency for the fuel-cell mode of operation is the inverse of Eqn. (5). It should be noted that the value of the thermal efficiency defined in this manner for electrolysis can exceed 1.0. As an example, for the reversible stoichiometric case, the cell potential approaches reference open-cell value, $E_{o}=\Delta G_{R} / 2 F$, yielding:

$$
\eta_{t, \max }=\frac{\Delta H_{R}}{\Delta G_{R}}
$$

which for steam electrolysis at $850^{\circ} \mathrm{C}$ is equal to 1.34 . For cases with variable gas concentrations, the open-cell potential is given by the Nernst Equation, which for the hydrogen/oxygen/steam system takes the form:

$$
E=E_{o}-\frac{R T}{j F} \ln \left[\left(\frac{y_{H 2 O}}{y_{H 2} y_{O 2}^{1 / 2}}\right)\left(\frac{P}{P_{s t d}}\right)^{-1 / 2}\right]
$$

FLUENT calculates the activation over-potential by the following set of equations. The parameter $i$, oref $_{\text {in }}$ is set at $1 \mathrm{e} 4$ $\mathrm{A} / \mathrm{m}^{2}$ for the oxygen electrode and $1 \mathrm{e} 8 \mathrm{~A} / \mathrm{m}^{2}$ for the hydrogen electrode [6]. FLUENT treats this effective current density as

$$
i_{0 e f f}=i_{0, r e f}\left(Y_{j}\right)^{\gamma}
$$

Where $\left(Y_{j}\right)$ is the mole fraction and $\gamma$ is the concentration exponent set to 0.5 . With $i$ being the local current density, the activation potential for the cathode and anode can then be calculated as:

$$
V_{a c t}=\frac{2 R T}{j F} \sinh ^{-1}\left(\frac{i}{i_{0 e f f}}\right)
$$

\section{RESULTS}

Results of the FLUENT simulations are presented in Figures 4 through 18. Figure 4 shows the operating voltage versus current for two different sets of conditions. Experimental results will be compared in future publications. The first condition corresponds to the INL test condition with a steam inlet mole fraction of 0.5 . The second condition is the MSRI suggested setup with an inlet steam mole fraction of 0.7 . In both cases the remaining flow is hydrogen. A sweep of 
various currents was performed for both conditions from -20.0 to 5.0 Amps. This was done by performing a simulation for each current shown in Figure 4. The activation overpotential is very low for these planar cells as noted in previous articles by the author and experimenters at the INL [8]. This is modeled by setting the exchange current density $\mathrm{i}_{0 \text { eff }}$ to a large value of $1 \mathrm{e} 8$ in the model. Experimental sweeps also show linear behavior from fuel cell to electrolysis modes, indicating very small activation overpotential.

Figure 5 shows a temperature contour plot of the outside of the cell at -20.0 Amps. The thick current collector top plate is cooler in the center due to the endothermicity of the reaction at -20.0 Amps. Some temperature smoothing has taken place between the cells and the top of the thick top plate, as the cells are cooler than the top of the plate at this condition (below thermal neutral). Black body radiation to the oven is assumed with an emissivity of 0.4 for all external surfaces. This is the only radiation heat transfer boundary condition in the model. The five cells are hotter than the thick stainless plates as they are insulated. Shown in Figure 6 are the temperature contours of a plane through one of the five electrolytes. Steam/hydrogen enters from the left and air/oxygen enters from the top. The top left corner is the most favorable region for the reaction to occur as it has the highest steam concentration and lowest oxygen concentration as shown in Eqn 7.

Stack voltage contours are displayed in Figure 7 for the ground, five oxygen side current collectors, and the current tap on the top. The per cell voltage at -20.0 Amps is $5.20 / 5$, or 1.04 $\mathrm{V}$. In order to achieve thermal neutral conditions for this cell, a voltage of $5 * 1.287 \mathrm{~V}$, or $6.435 \mathrm{~V}$ would be required. This would correspond to a large negative current according to Figure 4.

Figure 8 shows the hydrogen mole fraction contours as the flow passes through the cells. A mole fraction of 0.50 for hydrogen and steam is imposed in the inlet stream. For this current of -20.0 Amps, a hydrogen mole fraction of 0.70 is achieved at the exit of the cells. This corresponds to a mole fraction varying from 0.50 for the steam down to 0.30 as shown in Figure 9. The interesting note about these contour plots are the waves that appear as the flow passes through the cell. The flow comes out of the four inlet plenum holes and disperses across the cell active area. The only path to disperse to the areas between the holes is through the sideways path of the wire mesh. The flow into this area between the holes is most notable at the inlet and outlet areas as this is where the flow is trying to get into and out of these areas. These contour plots also indicate that the flow is evenly distributed between the five cells on the steam/hydrogen side and the air/oxygen side. Parametric studies were performed on the $\mathrm{x}-\mathrm{y}$ anisotropic permeability in the wire mesh. It is possible to impose such a small permeability in the wire mesh as to allow virtually no flow into this region, or to flow in very easily. A permeability of 1e-6 $\mathrm{m}^{2}$ was input for the $\mathrm{y}$ and $\mathrm{z}$ directions for the wire mesh and $1 \mathrm{e}-4 \mathrm{~m}^{2}$ for the $\mathrm{x}$ direction for the steam/hydrogen grill.
Figure 10 shows the mole fraction of the oxygen on the air/oxygen side. Air comes in with a mole fraction of 0.21 and exits around 0.26 . The highest oxygen concentration is in the bottom left corner as the most favorable area for the reaction is the top left corner. As the air/oxygen flows across the cell, the oxygen concentration increases.

Pressure contours (gauge pressures) are plotted in Figures 11 and 12 for the steam/hydrogen and air/oxygen current collectors respectively. Again it is difficult for the flow to enter the dead regions between the inlet holes and also difficult to exit these dead regions near the exit holes thus causing the waviness evident in the pressure contours. The magnitudes of the pressures are very small across the cell, only 160 and 330 $\mathrm{Pa}$.

Velocity vectors are plotted in a zoomed-in view of the inlet holes with the wire mesh areas in Figure 13. The velocity vectors show the flow entering into the dead region between the holes. This view is from the center two holes as the inlet tube is impinging directly between the two holes with most of the flow directly in line with the inlet tube.

Figure 14 shows pathlines of the steam/hydrogen flowing through the inlet tubes, through the inlet plenum and inlet holes, then flowing across the cells, gathering in the outlet holes, outlet plenum and outlet tube. Figure 15 reveals a recirculation pattern of the pathlines in the inlet plenum before it flows through the cells.

A current density contour plot is shown in Figure 16 on the electrolyte with the grid plotted for the inlet and outlet holes for the steam/hydrogen side for a current of -20.0 Amps. The largest current density occurs in the upper left corner as this is the most favorable region with the highest concentration of steam and lowest of oxygen. The waviness is also apparent in this view as the mole fractions of the steam/hydrogen dominate in the dead region downstream of the inlet holes.

Figure 17 shows the steam mole fraction for the INL test conditions for the single cell model at -20.0 Amps. The waves also exist in this model and nearly identical results occur for the single cell model. This fact that the results are the same for the single cell and five cell models indicates that a single cell model is adequate for future work.

Long inlet pipes and outlet pipes for the model were included to let the boundary layers develop. A velocity profile could have been used to simulate this developed boundary layer, but was not done so as to assure that the code calculated it as necessary. 


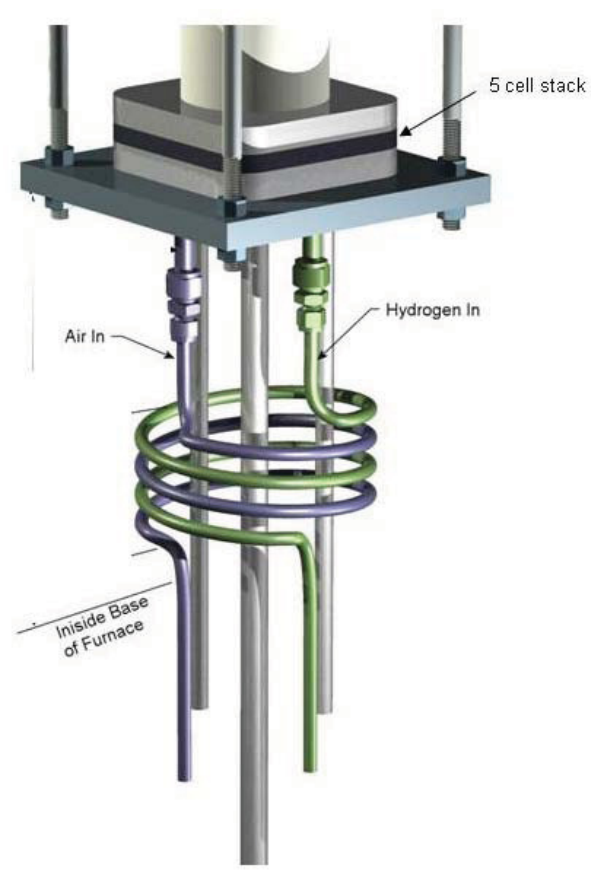

Figure 1. Apparatus setup.

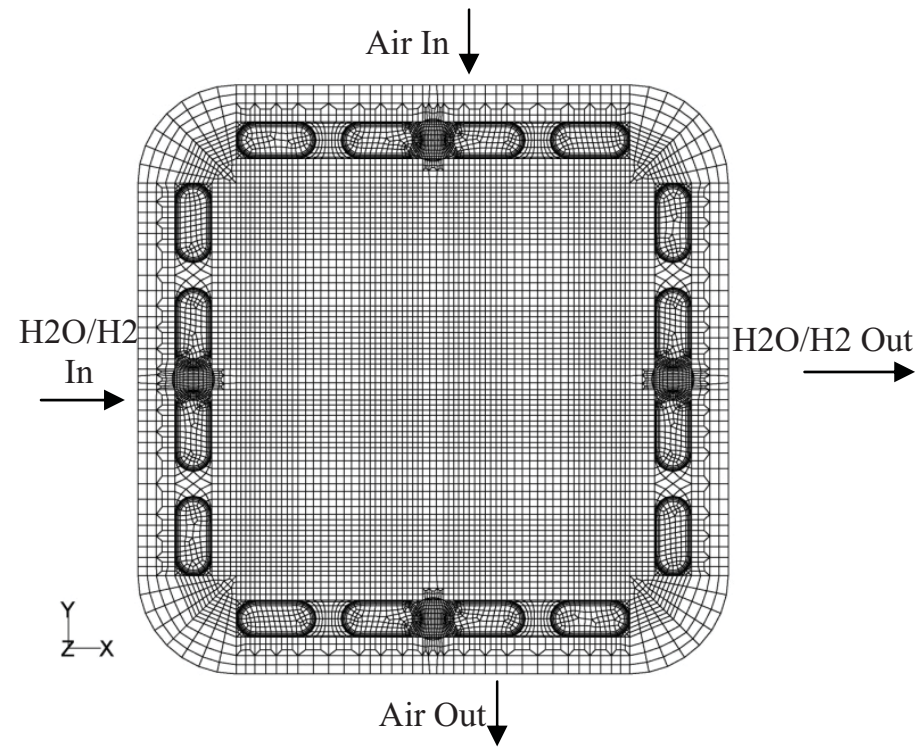

Figure 2. Surface mesh and flow directions.

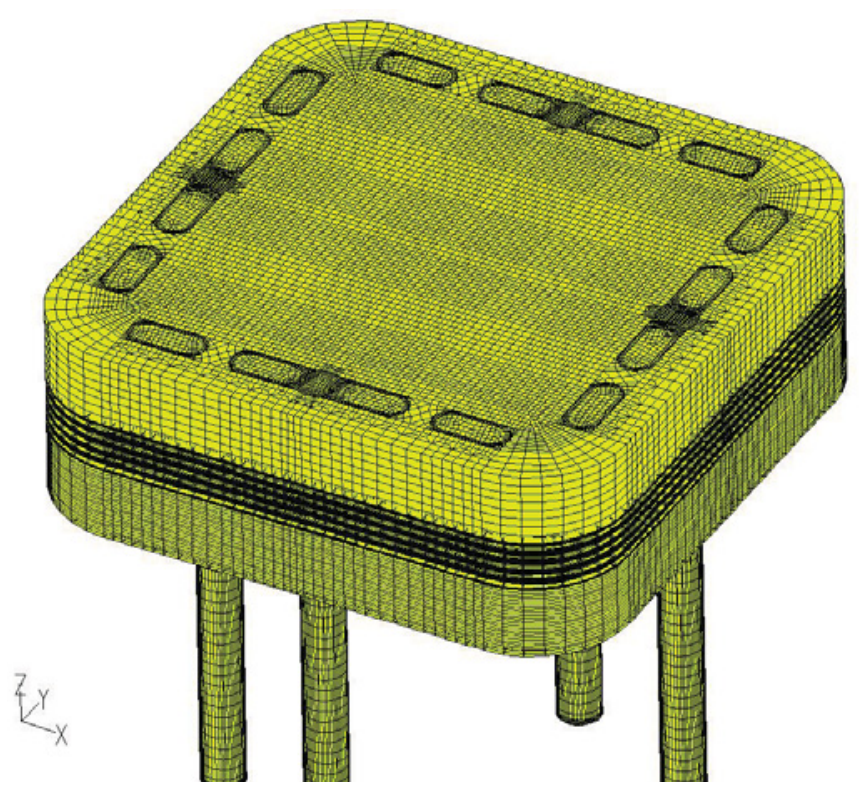

Figure 3. Three dimensional grid

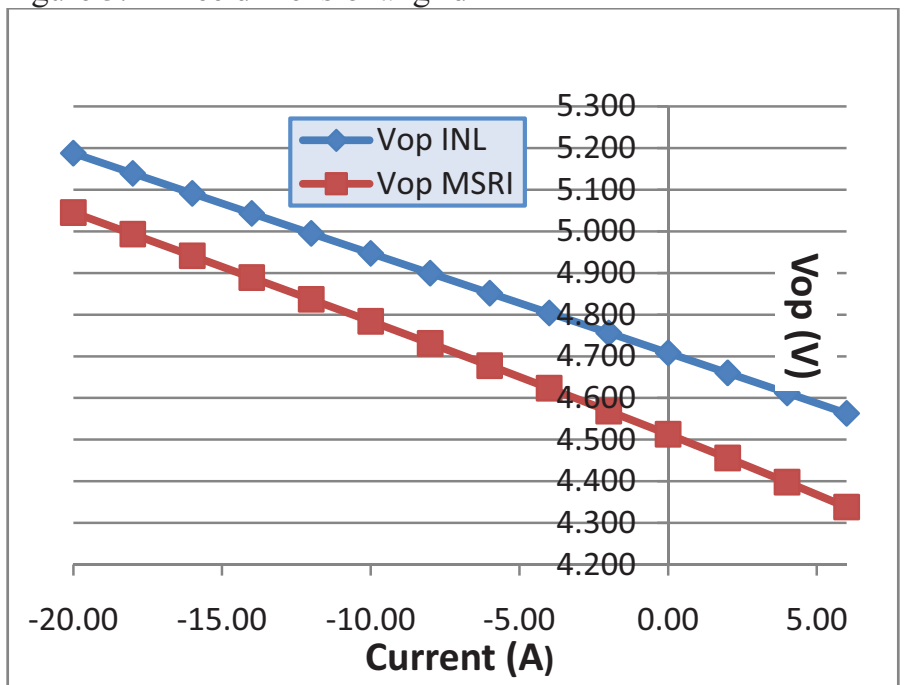

Figure 4. Operating voltage versus current for INL and MSRI test conditions.

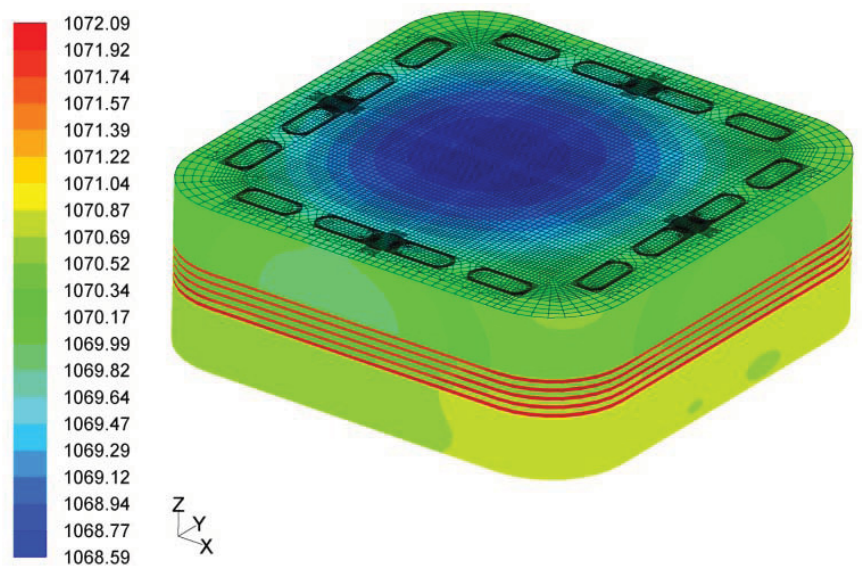

Figure 5. 3-D temperature contours (K) at -20.0 Amps. 

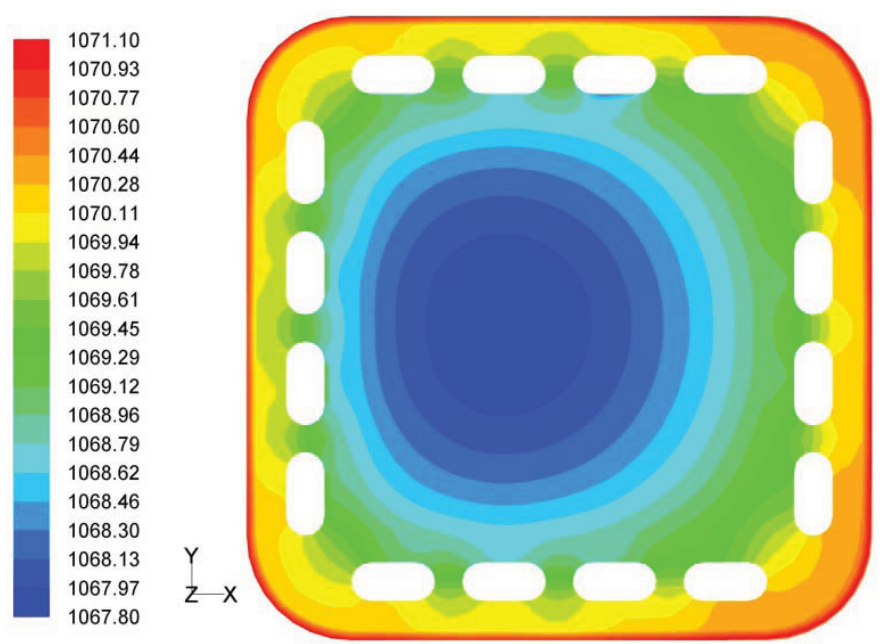

Figure 6. Temperature contours $(\mathrm{K})$ on an electrolyte plane at 20.0 Amps.

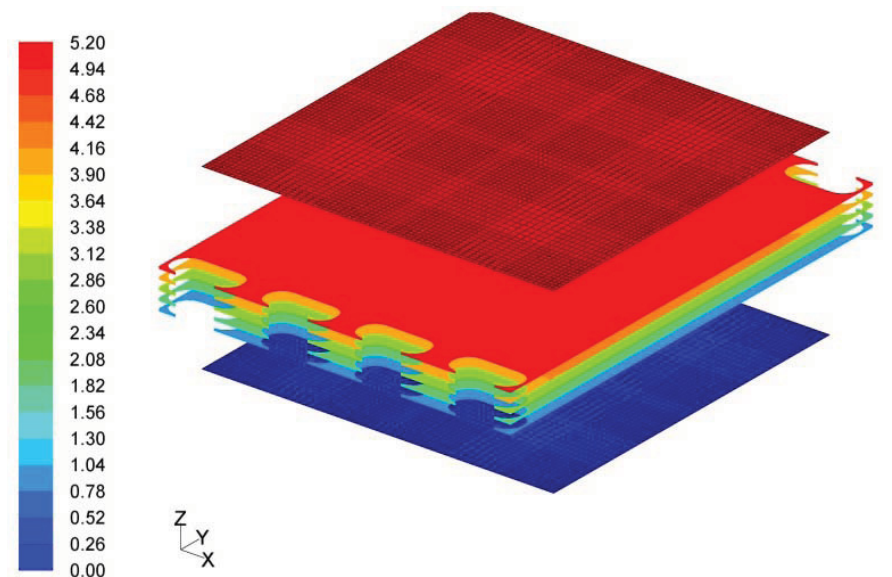

Figure 7. Voltage contours (V) at -20.0 Amps for ground, 5 separator plates, and current tap (on top).

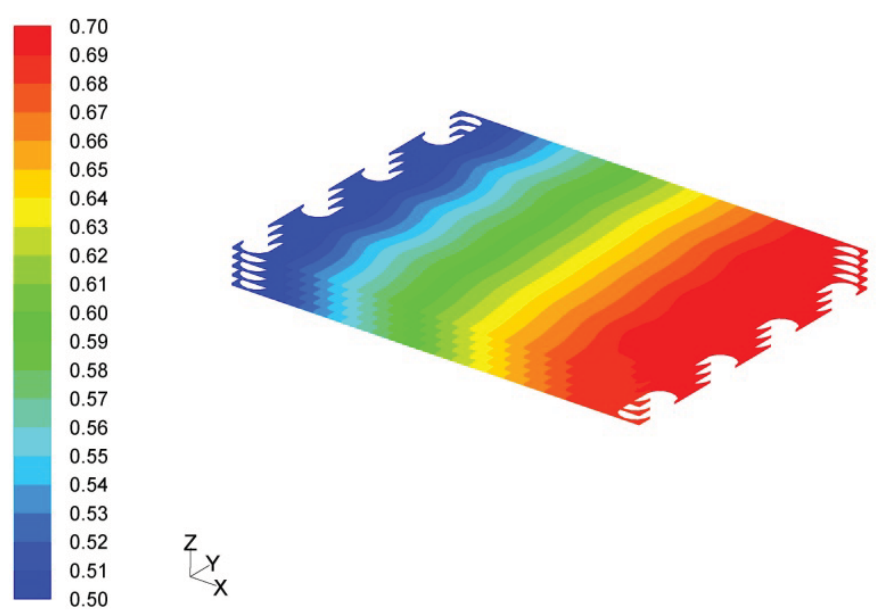

Figure 8. Hydrogen mole fraction for INL test conditions at 20.0 Amps.

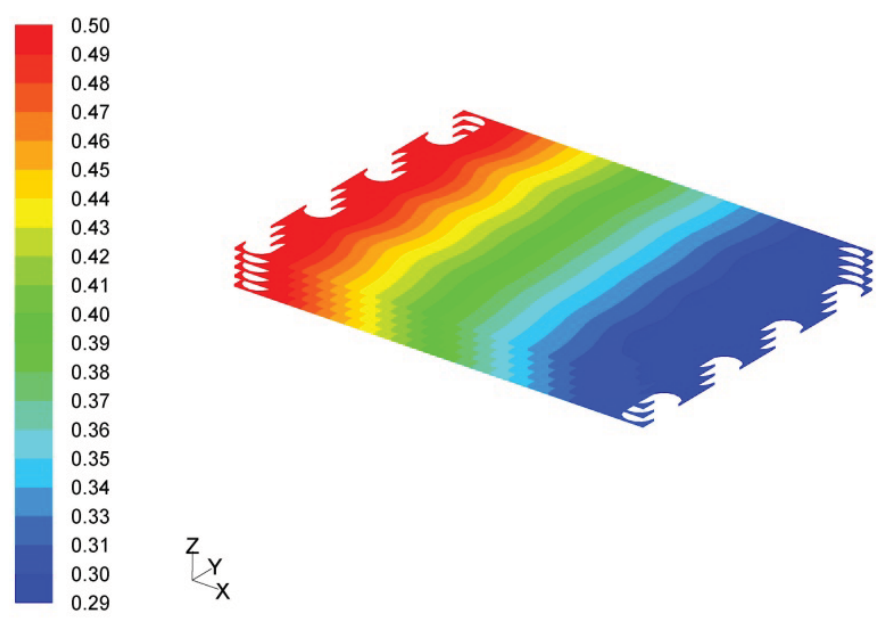

Figure 9. Steam mole fraction at $-20.0 \mathrm{Amps}$ for INL test conditions.

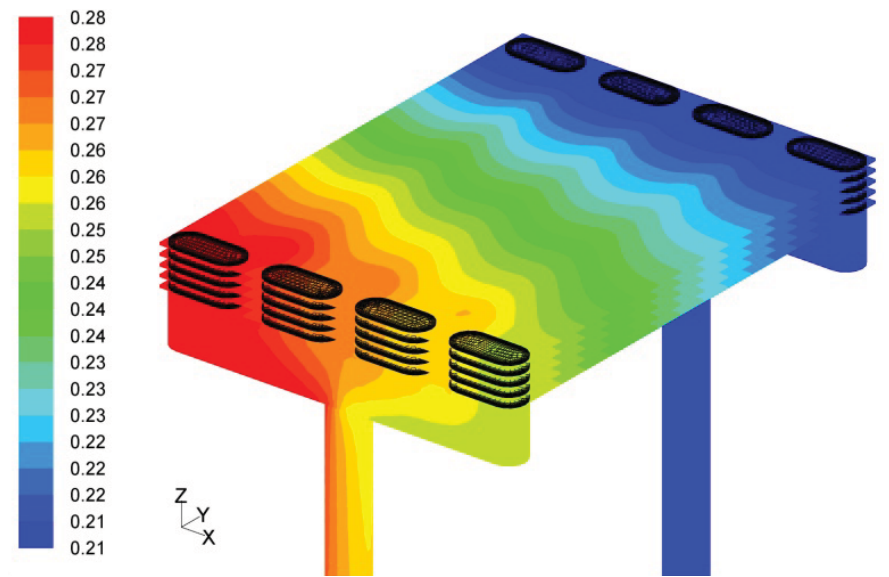

Figure 10. Oxygen mole fraction at -20.0 Amps with inlet and outlet tubes and plenums plotted.

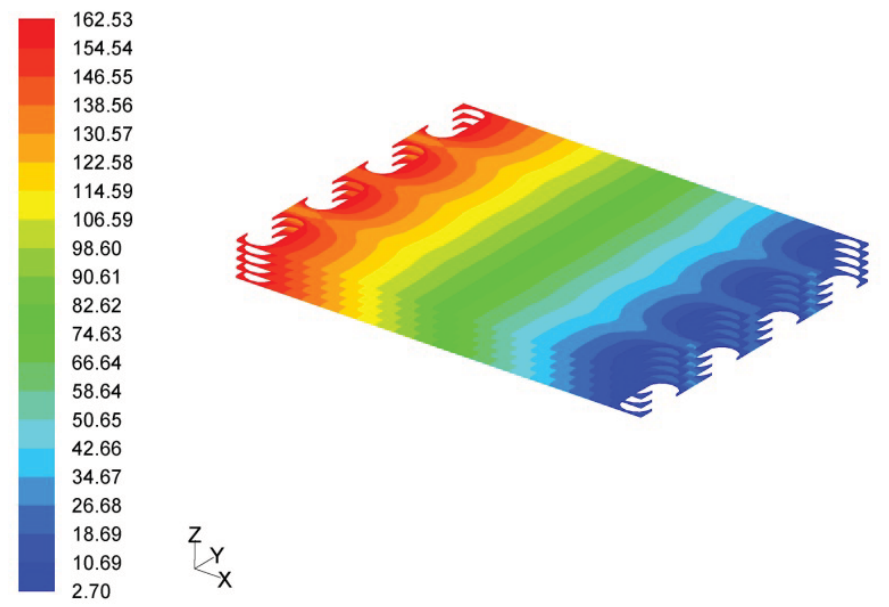

Figure 11. Pressure contours $(\mathrm{Pa})$ on steam/hydrogen side at 20.0 Amps. 


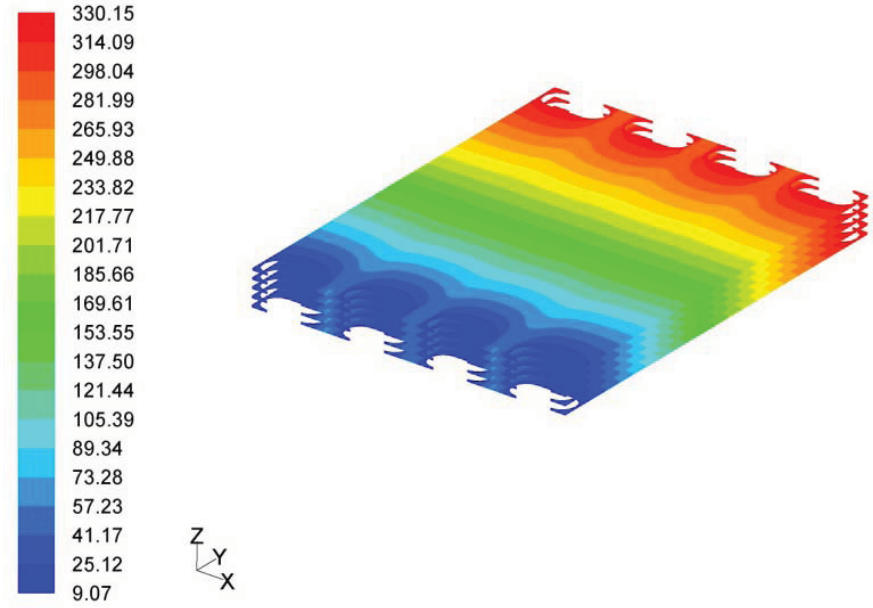

Figure 12. Pressure contours $(\mathrm{Pa})$ on air/oxygen side at -20.0 Amps.
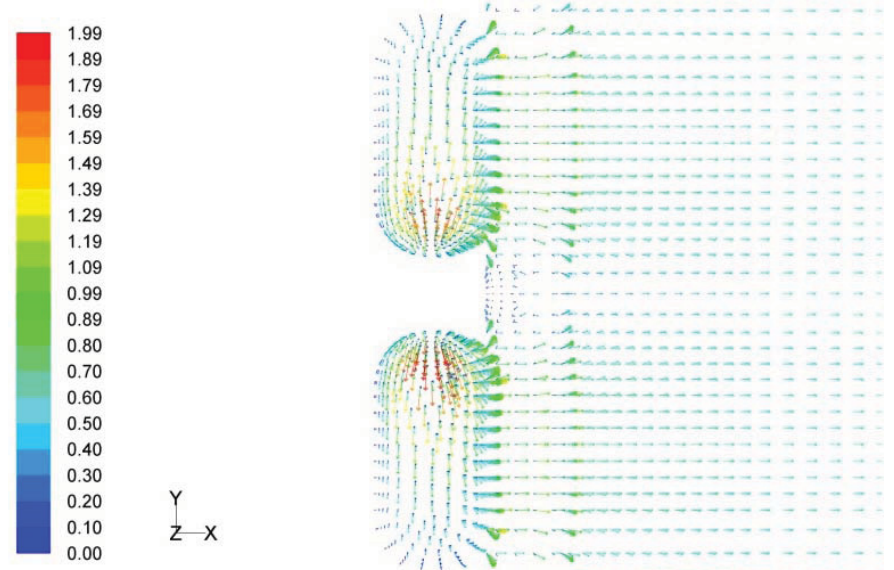

Figure 13 . Velocity vectors $(\mathrm{m} / \mathrm{s})$ in inlet holes and wire mesh on steam/hydrogen side at -20.0 Amps.

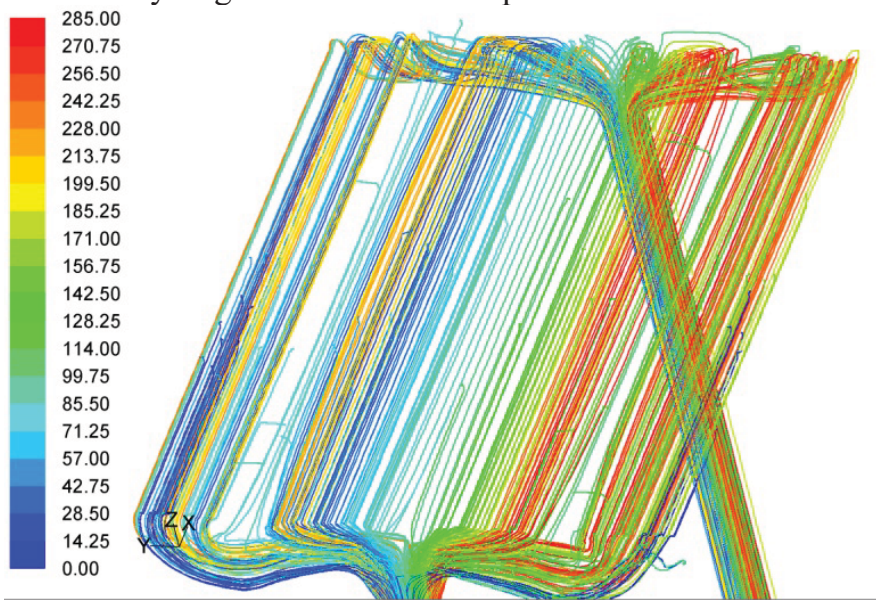

Figure 14. Pathlines through 5 cell stack with inlet and outlet tubes and plenums plotted.

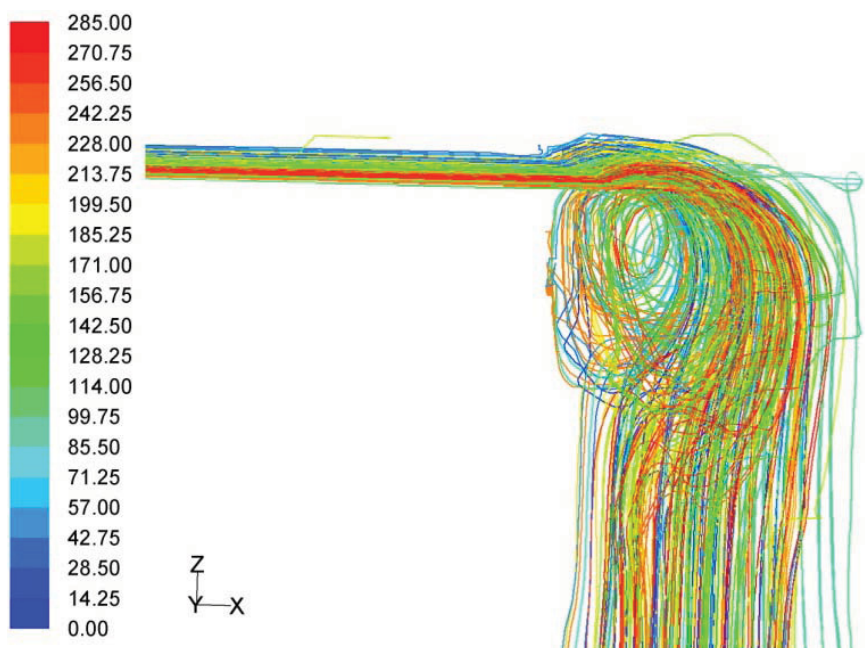

Figure 15. Pathlines showing recirculation in plenum before going through cells.

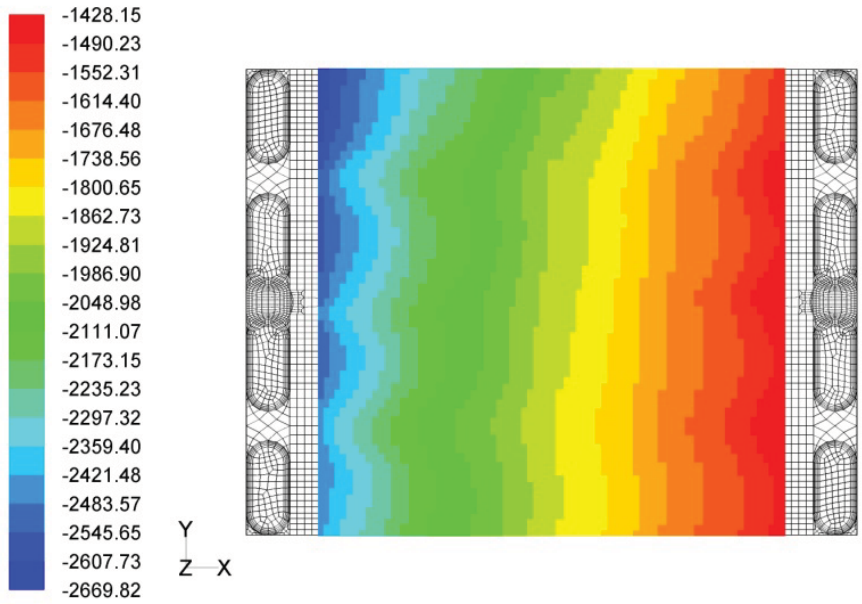

Figure 16. Current density $\left(\mathrm{A} / \mathrm{m}^{2}\right)$ on electrolyte at -20.0 Amps.

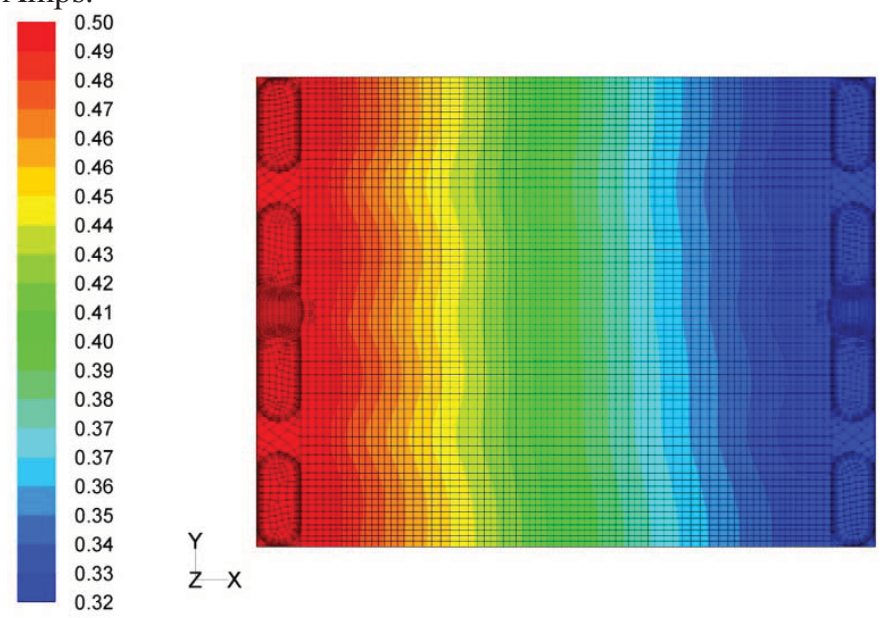

Figure 17. Steam mole fraction for single cell model at -20.0 Amps. 


\section{CONCLUSIONS}

A three dimensional computational fluid dynamics, heat transfer, and electrochemistry model has been created and evaluated for a five cell and single cell stack designed from the MSRI technology for an internally manifolded electrolysis cell. A current sweep was evaluated showing a linear voltage versus current indicating small activation overpotential. A uniform flow distribution when comparing cell to cell flow was found for the five cell stack. Dead regions of flow develop downstream of the area between the inlet holes and upstream of the outlet holes causing waves to appear in the contour plots of the mole fractions, pressure, and current density. Single cell and five cell results are nearly identical on a per cell basis showing that future calculations may be accurate with a single cell.

\section{ACKNOWLEDGMENTS}

Work supported by the U.S. Department of Energy, NGNP Program, Idaho Operations Office Contract

DE-AC07-05ID14517.

\section{COPYRIGHT STATEMENT}

This manuscript has been authored by Battelle Energy Alliance, LLC under Contract No. DE-AC07-05ID14517 with the U.S. Department of Energy. The United States Government retains and the publisher, by accepting the article for publication, acknowledges that the United States Government retains a nonexclusive, paid-up, irrevocable, world-wide license to publish or reproduce the published form of this manuscript, or allow others to do so, for United States Government purposes.

\section{REFERENCES}

[1] O'Brien, J. E., Stoots, C. M., Herring, J. S., and Hartvigsen, J. J., "Performance of Planar HighTemperature Electrolysis Stacks for Hydrogen
Production from Nuclear Energy," Nuclear Technology, Vol. 158, pp. 118 - 131, May, 2007.

[2] Herring, J. S., O’Brien, J. E., Stoots, C. M., and Hawkes, G. L., "Progress in High-Temperature Electrolysis for Hydrogen Production using Planar SOFC Technology," International Journal of Hydrogen Energy, Vol. 32, Issue 4, pp. 440-450, March 2007.

[3] Hawkes, G. L., O’Brien, J. E., and Stoots, C. M., “3D CFD Model of a Multi-Cell High Temperature Electrolysis Stack, in review, International Journal of Hydrogen Energy, 2008.

[4] Hawkes, G. L., O’Brien, J. E., Stoots, C. M., Herring, J. S., "CFD Model of a Planar Solid Oxide Electrolysis Cell for Hydrogen Production from Nuclear Energy," Nuclear Technology, Vol. 158, pp. 132 - 144, May, 2007.

[5] http://www.msrihome.com/index.html

[6] Hawkes, G. L., O’Brien, J. E., Stoots, C. M., Herring, J. S., and Jones, R. W., "CFD Model of a Planar Solid Oxide Electrolysis Cell: Base Case and Variations," paper \# HT2007-32310, 2007 ASME-JSME Thermal Engineering Conference and Summer Heat Transfer Conference, July 8-12, 2007, Vancouver, BC, Canada.

[7] Hawkes, G. L., O’Brien, J. E., “CFD Model of Electrode Supported Planar Solid Oxide Electrolysis Cells, paper no. 687d, AIChE Annual Mtg., Salt Lake City, UT, Nov. 12-17, 2010.

[8] Herring, J. S., O’Brien, J. E., Stoots, C. M., and Hawkes, G. L., "Progress in High-Temperature Electrolysis for Hydrogen Production using Planar SOFC Technology," International Journal of Hydrogen Energy, Vol. 32, Issue 4, pp. 440-450, March 2007. 